\title{
In tumor cells, thyroid hormone analogues non-immunologically regulate PD-L1 and PD-1 accumulation that is anti-apoptotic
}

\author{
Hung-Yun Lin ${ }^{1,2,3,4}$, Yu-Tang Chin ${ }^{1,2}$, Ya-Jung Shih ${ }^{1,2}$, Yi-Ru Chen ${ }^{1,2}$, Matthew \\ Leinung ${ }^{5}$, Kelly A. Keating ${ }^{6}$, Shaker A. Mousa ${ }^{6}$ and Paul J. Davis ${ }^{5,6}$ \\ ${ }^{1}$ PhD Program for Cancer Molecular Biology and Drug Discovery, College of Medical Science and Technology, Taipei Medical \\ University, Taipei, Taiwan \\ 2 Taipei Cancer Center, Taipei Medical University, Taipei, Taiwan \\ ${ }^{3}$ Traditional Herbal Medicine Research Center of Taipei Medical University Hospital, Taipei, Taiwan \\ ${ }^{4}$ TMU Research Center of Cancer Translational Medicine, Taipei Medical University, Taipei, Taiwan \\ ${ }^{5}$ Department of Medicine, Albany Medical College, Albany, NY, USA \\ ${ }^{6}$ Pharmaceutical Research Institute, Albany College of Pharmacy and Health Sciences, Rensselaer, NY, USA
}

Correspondence to: Paul J. Davis, email: pdavis.ordwayst@gmail.com

Keywords: L-thyroxine; PD-1/PD-L1 immune checkpoint; cancer; tetrac

Received: August 25, $2018 \quad$ Accepted: September 08, $2018 \quad$ Published: September 25, 2018

Copyright: Lin et al. This is an open-access article distributed under the terms of the Creative Commons Attribution License 3.0 (CC BY 3.0), which permits unrestricted use, distribution, and reproduction in any medium, provided the original author and source are credited.

\section{ABSTRACT}

The PD-1/PD-L1 immune checkpoint involving tumor cells and host immune defense lymphocytes is a well-studied therapeutic target in oncology. That PD-1 and PD-L1 may have additional functions within tumor cells that are independent of the checkpoint is indicated by actions of a thyroid hormone analogue, L-thyroxine $\left(T_{4}\right)$, on these checkpoint components. Acting at a cell surface receptor on plasma membrane integrin av $\beta 3, T_{4}$ stimulates intracellular accumulation of PD-L1 in cancer cells. In these thyroid hormone-treated cells, $T_{4}$-induced PD-L1 is nonimmunologically anti-apoptotic, blocking activation of p53. Several laboratories have also described accumulation of PD-1 in a variety of cancer cells, not just immune defense lymphocytes and macrophages. Preliminary observations indicate that $\mathbf{T}_{4}$ stimulates intracellular accumulation of PD-1 in tumor cells, suggesting that, like PDL1, PD-1 has non-immunologic roles in the setting of cancer. Where such roles are anti-apoptotic, thyroid hormone-directed cancer cell accumulation of PD-1 and PD-L1 may limit effectiveness of immunologic therapy directed at the immune checkpoint.

\section{INTRODUCTION}

The programmed death-1 (PD-1)/PD-Ligand 1 (PDL1) immune checkpoint has been extensively investigated [1-5]. PD-L1 production by tumor cells is a natural defense of cancer cells against host immune system destruction, downregulating the antitumor activity of immune $\mathrm{T}$ (killer) cells [1, 6-8]. Antibodies to PD-L1 and to PD-1 have been shown clinically to have important utility in the management of a variety of malignancies [9-15].

A non-antibody-based mechanism by which PDL1 elaboration by tumor cells can be regulated involves thyroid hormone analogues $[16,17]$. L-thyroxine $\left(\mathrm{T}_{4}\right)$ is the principal product of the thyroid gland and is viewed as prohormone for the major intracellular thyroid hormone,
3,5,3'-triiodo-L-thyronine $\left(\mathrm{T}_{3}\right)$. However, $\mathrm{T}_{4}$ has a panel of biological actions at a tumor cell surface receptor on plasma membrane integrin $\alpha v \beta 3$ [18]. One of these actions downstream of the receptor is upregulation of transcription of PD-L1 [16]. A derivative of $\mathrm{T}_{4}$, tetraiodothyroacetic acid (tetrac), blocks this action of $T_{4}$ initiated at $\alpha v \beta 3$. We have proposed that tetrac, modified chemically to limit its actions to the exterior of tumor cells expressing $\alpha v \beta 3$ [19], be tested as a non-antibody-based strategy to decrease or eliminate PD-L1 as a cancer cell defense [16].

\section{PD-L1 IN T 4 -TREATED TUMOR CELLS}

Thyroid hormone as $\mathrm{T}_{4}$ in physiological free concentrations supports cancer cell proliferation and a 
number of survival pathways in tumor cells [20]. These cancer support actions are initiated by $\mathrm{T}_{4}$ at a receptor site on the extracellular domain of integrin $\alpha v \beta 3$. While these actions are non-genomic at initiation - that is, they do not directly depend upon the nuclear receptors for thyroid hormone (TRs) - they may culminate downstream in transcription of specific genes [18], certain of which may involve TRs. These downstream effects are mediated by intracellular signal transduction systems, such as MAPK/ ERK and PI3K. Unmodified or chemically converted to a nanoparticle, tetrac blocks actions of $\mathrm{T}_{4}$, including activation of MAPK and PI3K.

The involvement of ERK $1 / 2$ and PI3K in the enhancement of $P D-L 1$ gene expression $[16,21]$ caused us to search for possible involvement of $\mathrm{T}_{4}$ in the regulation of $P D-L 1$ transcription. Studied in vitro in human breast and colon cancer cell lines, $P D-L 1$ expression was enhanced by $\mathrm{T}_{4}[16]$ and complimented by accumulation of tumor cell PD-L1 protein by as much as 2.7 -fold. Tetrac chemically bound to a poly lactic-co-glycolic acid (PLGA) nanoparticle, (Nanotetrac, nano-diamino-tetrac (NDAT)), substantially reduced the stimulatory effect of $\mathrm{T}_{4}$ on $P D$ L1 gene expression and on abundance of cellular PD-L1 protein. In addition to its anti-apoptotic property, PD-L1 may also be a proliferative factor in certain cancer cells [22]. These results support the possibility that circulating host $\mathrm{T}_{4}$ is contributing to defensive activation in cancer cells of PD-L1.

The NDAT results indicated the feasibility of using a small molecule to modulate the PD-1/PD-L1 checkpoint by reducing the availability of PD-L1 [23]. This approach would also avoid the systemic adverse effects of PD-L1 antibody $[24,25]$ because actions of NDAT are limited to cancer cells and rapidly dividing endothelial cells that generously express $\alpha v \beta 3$.

\section{NEWLY RECOGNIZED ROLES OF INTRACELLULAR PD-L1 AND PD-1 IN $\mathrm{T}_{4}$-TREATED CANCER CELLS}

Against the background described, it is reasonable to ask whether PD-L1 has clinically undesirable intracellular effects that also may be avoided by downregulating the transcription of $P D-L 1$ with NDAT or similar compounds. Resveratrol, a stilbene with anticancer properties, can induce p53-dependent apoptosis in cancer cells by a mechanism that involves nuclear uptake of cyclooxygenase-2 (COX-2) $[17,26]$. This was a novel role for COX-2.

Studied in the resveratrol-p53-COX-2 model in tumor cells exposed to $\mathrm{T}_{4}$, intracellular PD-L1 was found to be complexed with COX-2 in cytoplasm and no nuclear uptake of p53 and COX-2 occurred [17]. Therefore, resveratrol-induced apoptosis was inhibited. Thus, in addition to its function extracellularly as a ligand of T cell PD-1 at the PD-1/PD-L1 immune checkpoint and thus a defense against immune system destruction of cancer cells, PD-1 has an intracellular role as an inhibitor of inducible COX-2/p53-dependent apoptosis. This function is also a cancer cell survival mechanism for PD-L1. The results raise a set of questions that have not yet been addressed. For example, does the interaction of PD-L1 with inducible COX-2 in $\mathrm{T}_{4}$-treated tumor cells alter the function of COX-2 and reduce intracellular content of prostaglandins? Does this interaction model other proteinprotein interactions in cytoplasm that are relevant to
HT-29 cells

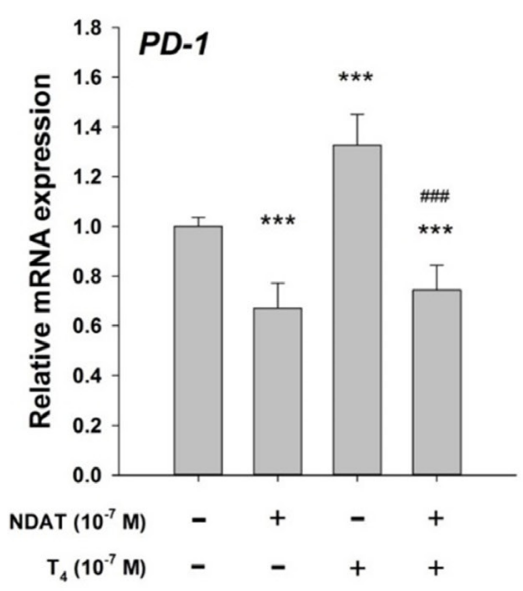

HCT116 cells

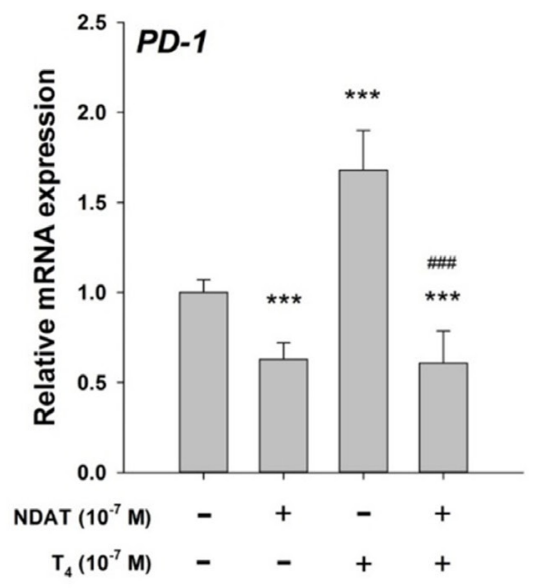

MDA-MB-231 cells

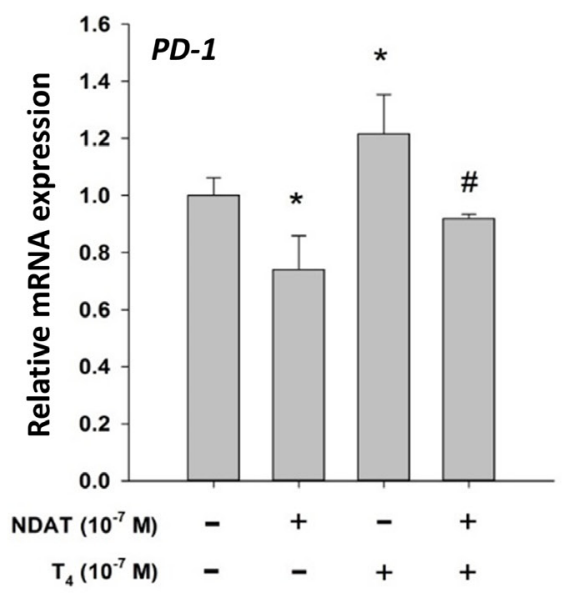

Figure 1: $\mathrm{T}_{4}$ induces $P D-1$ mRMA expression in human colon cancer (HT-29, HCT116 and breast cancer (MDAMB-231) cells in vitro. Nano-diamino-tetrac (NDAT) inhibits actions of $\mathrm{T}_{4}$ that are initiated at plasma membrane integrin $\alpha v \beta 3$ and has anticancer activity in the absence of $\mathrm{T}_{4}$. In this study, NDAT inhibited stimulatory activity of $\mathrm{T}_{4}$ on expression of $P D-1$ mRMA and also reduced abundance of $P D-1$ mRMA in the absence of $\mathrm{T}_{4}$. Materials, including cell lines, and methods used are as previously described [16].

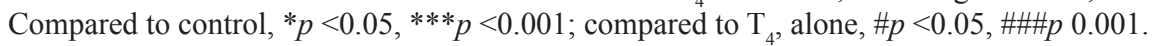


cancer cell defenses? The proteins could, for example, be signal transducing molecules or hormone-binding proteins such as nuclear thyroid hormone receptors (TRs) or estrogen receptors in cytoplasm.

The possibility that PD-1 has functions in cells other than $\mathrm{T}$ and $\mathrm{B}$ lymphocytes and macrophages has been suggested in reports from a number of laboratories that PD-1 is expressed by ovarian carcinoma cells [27], melanoma [28], small cell lung carcinoma [29], osteosarcoma cells [30] and murine lung carcinoma cells [31]. Physiological amounts of $\mathrm{T}_{4}$ induce expression of $P D-1$ mRMA as well as accumulation of PD-1 protein in several human cancer cell lines (HY Lin: unpublished observations). NDAT blocks the action of $\mathrm{T}_{4}$ on the PD-1 axis in these cancer cells (Figure 1). Such preliminary studies provide no functional basis for the PD-1 response in human tumor cells, but it is known that injured, nontumoral retinal ganglion cells (RGCs) express PD-1 [32], as do mouse RGCs scheduled to undergo apoptosis [33]. Thus, elaboration of PD-1 in cells other than lymphocytes and macrophages may be related to self-defense, e.g., apoptosis. This possibility requires systematic evaluation in other non-cancer cells.

\section{OVERVIEW}

That a thyroid hormone analogue such as $\mathrm{T}_{4}$ can regulate intracellular concentrations of PD-1 and PD-L1 by a mechanism that is inhibitable by NDAT indicates that $\mathrm{T}_{4}$ is indeed biologically active and its activity is manifested via the hormone receptor on integrin $\alpha v \beta 3 . \mathrm{T}_{4}$ is the principal ligand of this receptor [20,34], and NDAT at the concentration used is a specific inhibitor of thyroid hormone actions at $\alpha v \beta 3$ [16]. The transcription of a large number of genes is regulated by this cell surface hormone receptor [35], and many of these are relevant to tumor cell proliferation, to tumor cell survival anti-apoptotic pathways [20] and to rapidly dividing endothelial cells and angiogenesis $[36,37]$. We suggest that accumulation of intracellular PD-L1 and PD-1 in cancer cells offers another anti-apoptotic defense for tumor cells that is in a compartment inaccessible to clinically used antibodies to PD-1 and PD-L1 [23]. As noted above, accumulation of PD-L1 may occur in non-cancer cells that are at risk of apoptosis. Another role for PD-L1 involves regulation of angiogenesis [38]. Thus, distinct from their synergy in the function of the PD-1/PD-L1 immune checkpoint, these two moieties have functions as independent proteins. At least in part, these functions are regulated by thyroid hormone as $\mathrm{T}_{4}$.

Another issue is that resistance to apoptosis accompanies activation of the immune checkpoint in tumor cells [39]. Accumulation of PD-L1 and PD-1 within tumor cells exposed to $\mathrm{T}_{4}$ may be a component of the antiapoptosis encountered in checkpoint activation.

$\mathrm{T}_{4}$ is known to have pro-angiogenic and anti- apoptotic properties [18], and the independent control by $T_{4}$ via $\alpha v \beta 3$ of PD- 1 and PD-L1 production unrelated to the PD-1/PD-L1 immune checkpoint is consistent with roles already defined for $\mathrm{T}_{4}$. While further studies are required to determine how substantial the clinical contributions are of $\mathrm{T}_{4}$ to tumor-related angiogenesis and anti-apoptosis, elimination of $\mathrm{T}_{4}$ in patients with advanced cancers has shown stabilization of the disease and extended survival [40].

\section{CONFLICTS OF INTEREST}

Co-authors PJ Davis and SA Mousa are stockholders in NanoPharmaceuticals LLC that is commercially developing NDAT, and PJ Davis is an officer of the company. KA Keating is a paid consultant for NanoPharmaceuticals LLC. Co-authors Lin, Chin, Shih, Chen, and Leinung have no conflicts to report.

\section{FUNDING}

This work was supported in part by the "TMU Research Center of Cancer Translational Medicine" from The Featured Areas Research Center Program within the framework of the Higher Education Sprout Project by the Ministry of Education (MOE) in Taiwan and grants from Ministry of Science and Technology, Taiwan (MOST 1042314-B-038-046 -MY3; MOST105-2320-B-038-006).

\section{REFERENCES}

1. Alsaab HO, Sau S, Alzhrani R, Tatiparti K, Bhise K, Kashaw SK, Iyer AK. PD-1 and PD-L1 checkpoint signaling inhibition for cancer immunotherapy: Mechanism, combinations, and clinical outcome. Front Pharmacol. 2017; 8:561.

2. Maleki Vareki S, Garrigos C, Duran I. Biomarkers of response to PD-1/PD-L1 inhibition. Crit Rev Oncol Hematol. 2017; 116:116-124.

3. Shien K, Papadimitrakopoulou VA, Wistuba II. Predictive biomarkers of response to PD-1/PD-L1 immune checkpoint inhibitors in non-small cell lung cancer. Lung Cancer. 2016; 99:79-87. https://doi.org/10.1016/j.lungcan.2016.06.016.

4. Dijkstra KK, Voabil P, Schumacher TN, Voest EE. Genomics- and transcriptomics-based patient selection for cancer treatment with immune checkpoint inhibitors: A review. JAMA Oncol. 2016; 2:1490-1495.

5. Gong J, Chehrazi-Raffle A, Reddi S, Salgia R. Development of PD-1 and PD-L1 inhibitors as a form of cancer immunotherapy: A comprehensive review of registration trials and future considerations. J Immunother Cancer. 2018; 6:8.

6. Sun C, Mezzadra R, Schumacher TN. Regulation and function of the PD-L1 checkpoint. Immunity. 2018; 48:434452. 
7. Wang Q, Liu F, Liu L. Prognostic significance of PDL1 in solid tumor: An updated meta-analysis. Medicine (Baltimore). 2017; 96:e6369.

8. Balar AV, Weber JS. PD-1 and PD-L1 antibodies in cancer: current status and future directions. Cancer Immunol Immunother. 2017; 66:551-564.

9. Annibali O, Crescenzi A, Tomarchio V, Pagano A, Bianchi A, Grifoni A, Avvisati G. PD-1 /PD-L1 checkpoint in hematological malignancies. Leuk Res. 2018; 67:45-55.

10. Hsu FS, Su CH, Huang KH. A comprehensive review of US FDA-approved immune checkpoint inhibitors in urothelial carcinoma. J Immunol Res. 2017; 2017:6940546.

11. Kordbacheh T, Honeychurch J, Blackhall F, Faivre-Finn C, Illidge T. Radiotherapy and anti-PD-1/PD-L1 combinations in lung cancer: Building better translational research platforms. Ann Oncol. 2018; 29:301-310.

12. Polk A, Svane IM, Andersson M, Nielsen D. Checkpoint inhibitors in breast cancer - Current status. Cancer Treat Rev. 2018; 63:122-134.

13. Moris D, Rahnemai-Azar AA, Zhang X, NtanasisStathopoulos I, Tsilimigras DI, Chakedis J, Argyrou C, Fung JJ, Pawlik TM. Program death-1 immune checkpoint and tumor microenvironment in malignant liver tumors. Surg Oncol. 2017; 26:423-430.

14. De Meulenaere A, Vermassen T, Aspeslagh S, Huvenne W, Van Dorpe J, Ferdinande L, Rottey S. Turning the tide: Clinical utility of PD-L1 expression in squamous cell carcinoma of the head and neck. Oral Oncol. 2017; 70:3442.

15. Chau I. Clinical development of PD-1/PD-L1 immunotherapy for gastrointestinal cancers: Facts and hopes. Clin Cancer Res. 2017; 23:6002-6011.

16. Lin HY, Chin YT, Nana AW, Shih YJ, Lai HY, Tang HY, Leinung M, Mousa SA, Davis PJ. Actions of L-thyroxine and Nano-diamino-tetrac (Nanotetrac) on PD-L1 in cancer cells. Steroids. 2016; 114:59-67.

17. Chin YT, Wei PL, Ho Y, Nana AW, Changou CA, Chen YR, Yang YS, Hsieh MT, Hercbergs A, Davis PJ, Shih YJ, Lin HY. Thyroxine inhibits resveratrol-caused apoptosis by PD-L1 in ovarian cancer cells. Endocr Relat Cancer. 2018; 25:533-545

18. Davis PJ, Goglia F, Leonard JL. Nongenomic actions of thyroid hormone. Nat Rev Endocrinol. 2016; 12:111-121.

19. Bharali DJ, Yalcin M, Davis PJ, Mousa SA. Tetraiodothyroacetic acid-conjugated PLGA nanoparticles: a nanomedicine approach to treat drug-resistant breast cancer. Nanomedicine (Lond). 2013; 8:1943-1954.

20. Lin HY, Chin YT, Yang YC, Lai HY, Wang-Peng J, Liu LF, Tang HY, Davis PJ. Thyroid hormone, cancer, and apoptosis. Compr Physiol. 2016; 6:1221-1237.

21. Ritprajak P, Azuma M. Intrinsic and extrinsic control of expression of the immunoregulatory molecule PD-L1 in epithelial cells and squamous cell carcinoma. Oral Oncol. 2015; 51:221-228.
22. Lin SJ, Chin YT, Ho Y, Chou SY, Sh Yang YC, Nana AW, Su KW, Lim YT, Wang K, Lee SY, Shih YJ, Chen YR, Whang-Peng J, et al. Nano-diamino-tetrac (NDAT) inhibits PD-L1 expression which is essential for proliferation in oral cancer cells. Food Chem Toxicol. 2018; 120:1-11.

23. Davis PJ, Mousa SA, Lin HY. Tetraiodothyroacetic acid (tetrac), integrin $\alpha v \beta 3$ and disabling of immune checkpoint defense. Future Med Chem. 2018; 10:1637-1639.

24. O’Malley G, Lee HJ, Parekh S, Galsky MD, Smith CB, Friedlander P, Yanagisawa RT, Gallagher EJ. Rapid evolution of thyroid dysfunction in patients treated with nivolumab. Endocr Pract. 2017; 23:1223-1231.

25. Yamauchi I, Sakane Y, Fukuda Y, Fujii T, Taura D, Hirata M, Hirota K, Ueda Y, Kanai Y, Yamashita Y, Kondo E, Sone M, Yasoda A, et al. Clinical features of nivolumabinduced thyroiditis: A case series study. Thyroid. 2017; 27:894-901.

26. Cheng TM, Chin YT, Ho Y, Chen YR, Yang YN, Yang YC, Shih YJ, Lin TI, Lin HY, Davis PJ. Resveratrol induces sumoylated COX-2-dependent anti-proliferation in human prostate cancer LNCaP cells. Food Chem Toxicol. 2018; 112:67-75.

27. Darb-Esfahani S, Kunze CA, Kulbe H, Sehouli J, Wienert S, Lindner J, Budczies J, Bockmayr M, Dietel M, Denkert C, Braicu I, Jöhrens K. Prognostic impact of programmed cell de ath-1 (PD-1) and PD-ligand 1 (PD-L1) expression in cancer cells and tumor-infiltrating lymphocytes in ovarian high grade serous carcinoma. Oncotarget. 2016; 7:1486-99. https://doi.org/10.18632/oncotarget.6429.

28. Mirkina I, Hadzijusufovic E, Krepler C, Mikula M, Mechtcheriakova D, Strommer S, Stella A, Jensen-Jarolim E, Holler C, Wacheck V, Pehamberger H, Valent P. Phenotyping of human melanoma cells reveals a unique composition of receptor targets and a subpopulation coexpressing ErbB4, EPO-R and NGF-R. PLoS One. 2014; 9:e84417.

29. Yamane H, Isozaki H, Takeyama M, Ochi N, Kudo K, Honda Y, Yamagishi T, Kubo T, Kiura K, Takigawa N. Programmed cell death protein 1 and programmed deathligand 1 are expressed on the surface of some small-cell lung cancer lines. Am J Cancer Res. 2015; 5:1553-1557.

30. Zhao F, Wu Q, Dai X, Li Y, Gan H, Wang R, Lv J, Chen Y. Programmed cell death 1 correlates with the occurrence and development of MG63 osteosarcoma. Oncol Lett. 2016; 12:5199-5204.

31. Akbay EA, Koyama S, Carretero J, Altabef A, Tchaicha JH, Christensen CL, Mikse OR, Cherniack AD, Beauchamp EM, Pugh TJ, Wilkerson MD, Fecci PE, Butaney M, et al. Activation of the PD-1 pathway contributes to immune escape in EGFR-driven lung tumors. Cancer Discov. 2013; 3:1355-1363.

32. Wang W, Chan A, Qin Y, Kwong JMK, Caprioli J, Levinson R, Chen L, Gordon LK. Programmed cell death-1 is expressed in large retinal ganglion cells and is upregulated after optic nerve crush. Exp Eye Res. 2015; 
140:1-9.

33. Chen L, Sham CW, Chan AM, Francisco LM, Wu Y, Mareninov S, Sharpe AH, Freeman GJ, Yang XJ, Braun J, Gordon LK. Role of the immune modulator programmed cell death-1 during development and apoptosis of mouse retinal ganglion cells. Invest Ophthalmol Vis Sci. 2009; 50:4941-4948.

34. Lin HY, Landersdorfer CB, London D, Meng R, Lim CU, Lin C, Lin S, Tang HY, Brown D, Van Scoy B, Kulawy R, Queimado L, Drusano GL, et al. Pharmacodynamic modeling of anti-cancer activity of tetraiodothyroacetic acid in a perfused cell culture system. PLoS Comput Biol. 2011; 7:e1001073.

35. Davis PJ, Glinsky GV, Lin HY, Leith JT, Hercbergs A, Tang HY, Ashur-Fabian O, Incerpi S, Mousa SA. Cancer cell gene expression modulated from plasma membrane integrin $\alpha v \beta 3$ by thyroid hormone and nanoparticulate tetrac. Front Endocrinol (Lausanne). 2015; 5:240.

https://doi.org/10.3389/fendo.2014.00240.
36. Lin HY, Glinsky GV, Mousa SA, Davis PJ. Thyroid hormone and anti-apoptosis in tumor cells. Oncotarget. 2015; 6:14735-43.

https://doi.org/10.18632/oncotarget.4023.

37. Davis PJ, Sudha T, Lin HY, Mousa SA. Thyroid hormone, hormone analogs, and angiogenesis. Compr Physiol. 2015; 6:353-362.

38. Jin Y, Chauhan SK, El Annan J, Sage PT, Sharpe AH, Dana R. A novel function for programmed death ligand-1 regulation of angiogenesis. Am J Pathol. 2011; 178:19221929.

39. Marcucci F, Rumio C, Corti A. Tumor cell-associated immune checkpoint molecules - Drivers of malignancy and stemness. Biochim Biophys Acta. 2017; 1868:571-583.

40. Hercbergs A, Johnson RE, Ashur-Fabian O, Garfield DH, Davis PJ. Medically induced euthyroid hypothyroxinemia may extend survival in compassionate need cancer patients: an observational study. Oncologist. 2015; 20:72-76. 